Article

\title{
The Problem of Fit in Flood Risk Governance: Regulative, Normative, and Cultural-Cognitive Deliberations
}

\author{
Per Becker 1,2,3 \\ ${ }^{1}$ Division of Risk Management and Societal Safety, Lund University, 22100 Lund, Sweden; E-Mail: per.becker@risk.lth.se \\ 2 Risk and Crisis Research Centre, Mid Sweden University, 83125 Östersund, Sweden \\ ${ }^{3}$ Unit for Environmental Sciences and Management, North-West University, 2520 Potchefstroom, South Africa
}

Submitted: 26 March 2020 | Accepted: 27 May 2020 | Published: 10 December 2020

\begin{abstract}
Flood risk is a growing global concern that is not only affecting developing countries, but also the sustainable development of the most affluent liberal democracies. This has attracted attention to the systems governing flood risk across administrative levels, which vary between countries, but are relatively similar in the Nordic region, with both responsibilities and resources largely decentralized to the municipal level. However, floods tend not to be bounded by conventional borders but demand attention to the catchment area as a whole. Influential voices have long argued the importance of fit between the biophysical basis of an issue and the institutional arrangements of actors engaging in its governance. The article investigates such institutional fit in flood risk governance, based on a case study of flood risk mitigation in the Höje $\AA$ catchment area in Southern Sweden. Analyzing a unique dataset comprising 217 interviews with all individual formal actors actively engaged in flood risk mitigation in the catchment area illuminates a 'problem of fit' between the hydrological system behind flood risk and the institutional arrangements of its governance. This 'problem of fit' is not only visible along the borders of the municipalities composing the catchment area, but also of the spatial planning areas within them. The article deliberates on regulative, normative, and cultural-cognitive elements that align to lock flood risk governance into a regime of practices that, if not addressed, continues to undermine society's ability to anticipate and adapt to the expected escalation of flood risk in a changing climate.
\end{abstract}

\section{Keywords}

flood risk; governance; governmentalization; institutional fit; institutionalism; mitigation; problem of fit; Sweden

Issue

This article is part of the issue "The Politics of Disaster Governance" edited by Dorothea Hilhorst (Erasmus University Rotterdam, The Netherlands), Kees Boersma (Vrije Universiteit Amsterdam, The Netherlands) and Emmanuel Raju (University of Copenhagen, Denmark).

(C) 2020 by the author; licensee Cogitatio (Lisbon, Portugal). This article is licensed under a Creative Commons Attribution 4.0 International License (CC BY).

\section{Introduction}

Flood risk is a great and growing global concern (Alfieri et al., 2017; Grobicki, Macleod, \& Pischke, 2015) that is not only affecting developing countries, but threatens to undermine sustainable development also in the most affluent advanced liberal democracies (Priest et al., 2016). This has spurred intense scientific interest in the systems governing flood risk across administrative levels (Bergsma, 2019; Johannessen et al., 2019; Thaler \& Levin-Keitel, 2016). Flood risk is exacerbated by climate change (Becker, 2014), whose message spreads to all corners of the world, constituting, as well as being constituted by, local institutional dynamics that shape both processes and outcomes (Artur \& Hilhorst, 2017). These systems thus vary between countries, but are relatively similar in the Nordic region, with both responsibilities and resources largely decentralized to the municipal level (Harjanne et al., 2016).

Floods tend not to be bounded by geopolitical, administrative, or organizational borders, but demand attention to the catchment area as a whole (Niemczynowicz, 1999, p. 12). Flood risk must thus be jointly governed by networks of actors (Becker, 2018; 
Renn, 2008). The patterns of social relations among these actors are fundamental for society's capacity to reduce risk (Ingold, Balsinger, \& Hirschi, 2010) and influential voices have long argued the importance of fit between the biophysical basis of an issue and the institutional arrangements of actors engaging in its governance (Folke, Lowell Pritchard, Berkes, Colding, \& Svedin, 2007; Young \& Underdal, 1997). Such problems of fit have been shown to potentially undermine effective problemsolving in a wide range of contexts (e.g., Bergsten et al., 2019; Bodin \& Nohrstedt, 2016), including flood risk governance (e.g., Bergsma, 2019; Krieger, 2013; Lebel, Nikitina, Pahl-Wostl, \& Knieper, 2013). However, this literature is overwhelmingly focused on the institutional level as such (macro), or on the interaction between organizations (meso), with little or no attention to the level of the interacting individuals who constitute the organizations and reproduce the institutions (micro). Moreover, the micro-level studies that do exist in the context of flood risk governance are largely focusing on the reactive response to floods, often using social media data (e.g., Kim \& Hastak, 2018), and not to the same extent on the proactive mitigation of flood risk.

The purpose of this article is therefore to investigate the institutional fit between the hydrology of a catchment area and the regime of practices of individual actors governing flood risk mitigation in Sweden. The article intends to meet that purpose by answering the following research question: How is the institutional fit of the governing of flood risk mitigation in Höje Å catchment area in Sweden?

\section{Theoretical Framework}

Floods are complex phenomena and any specific flood can be the result of a combination of pluvial, fluvial, coastal, and groundwater processes (Becker, 2018). Although risk is a contested concept, it is here defined as uncertainty about what could happen and what the consequences would be (Aven \& Renn, 2009). There is nowadays widespread agreement that flood risk emerges in the intersection of hazard and vulnerability (Di Baldassarre et al., 2018; Grahn \& Nyberg, 2017; Wisner, Blaikie, Cannon, \& Davis, 2004), which is where the attention must be placed to make any sense of uncertainty and consequences in relation to floods. However, it is important to note that there is nothing objective about risk, since any notion of it is based on perceptions, is culturally mediated, and can be socially amplified (Renn, 2008). Flood risk mitigation is here defined as comprising all proactive activities that reduce the likelihood of floods and/or their consequences before occurring (Coppola, 2011), by addressing either the flood hazard, the vulnerability to the impact of floods, or both (Wisner et al., 2004).

Floods are not bounded by conventional borders (Becker, 2018). The only boundaries known to water are hydrological since it can only flow downstream. The essential entity for understanding and governing flood risk is therefore the catchment area (Niemczynowicz, 1999, p. 12), which is, simply put, an area within which all rainfall eventually ends up in the same place (Davie, 2008). While the importance of the catchment perspective is clearly pointed out in the EU Floods Directive (EU, 2007) and in Swedish legislation (Swedish Parliament, 2009), it is rarely applied in practice (Johannessen \& Granit, 2015; Norén, Hedelin, Nyberg, \& Bishop, 2016).

Risk governance has been approached from many different perspectives (e.g., Hood, Rothstein, \& Baldwin, 2001; Renn, 2008). In contrast to traditional risk management, it emphasizes situations with many actors, multiple and often conflicting values, and no single authority to make binding decisions (Renn, 2008). It examines "the complex web of actors, rules, conventions, processes and mechanisms" (Renn, 2008, p. 9). Studying the governing of flood risk mitigation entails therefore attention to the patterns of social relations among involved actors (Becker, 2018; Ingold et al., 2010). Since the roles of actors are defined both by their social relations and by the institutional context they are embedded into (DiMaggio, 1992), studying the governing of flood risk mitigation also entails attention to the regulative, normative and cultural-cognitive elements making up these institutions (Scott, 2014). Such a new institutionalism perspective has become incredibly influential in organizational analysis (Scott, 2014) and has been suggested an important complement in the study of social-ecological interactions (Hotimsky, Cobb, \& Bond, 2006).

Social relations are not only formed because actors are dependent upon each other, but also when actors convince each other that their problems or objectives are shared or linked, and can be addressed together (Miller \& Rose, 2008). Regardless of how they are formed, they denote some kind of dependence after being established (Luhmann, 1979). One way of identifying the involved actors is thus to start with actors known to contribute actively to mitigating flood risk and trace who they are dependent on input from to do it. Becker (2018) suggests a framework of seven types of input that is deemed sufficient for the purpose of this study: reports of activities, equipment and material, funding, technical information, rules and policy, advice and technical support, and pepping and moral support.

Emirbayer (1997) suggests that a relational perspective is indispensable for linking micro-, meso-, and macrolevels, as it allows for reconceptualizing distinct sui generis levels of analysis on a continuum between interacting individuals and society. However, there are different empirical approaches to this relationality: Structural approaches that represent various social relations formally to be analyzed using graphical or mathematical methods (Berkowitz, 1982; Wellman, 1988), and interpretative approaches that study their meaning and the context they are embedded into (Goffman, 1982; Joas, 1987). Although this division has often been defined by disagreement (Emirbayer \& Goodwin, 1994), it is 
only through their combination that the relational perspective can become whole (Crossley, 2010; Fuhse \& Mützel, 2011).

Social network analysis has been suggested the most developed and widely used structural approach (Emirbayer, 1997, p. 298), facilitating linking different levels of analysis (Crossley, 2010; Granovetter, 1973). It has no inherent or preferred level of analysis apart from the degree of abstraction currently applied (Nadel, 1957, pp. 97-124), with the only restriction being the fundamental unit of analysis of the particular study. In this case, the social relation between individual actors. The interpretative approach utilized in this article also focuses on connecting these levels by building from bottom-up (Fine, 1993); inquiring into the actions and interactions of individual actors. This investigation of the institutional fit of the governing of flood risk mitigation thus integrates social network analysis and qualitative analysis.

Social network analysis comprises of a broad range of analytical instruments, out of which two different centrality measures are particularly useful for the purpose of this article; in-degree centrality and directional betweenness centrality (Borgatti, Everett, \& Johnson, 2018). The more an actor has many actors highly dependent on her input, the more local control she has over resourceshere operationalized as in-degree centrality-while the more an actor falls on the shortest paths between pairs of other actors, the more control she has over resource flows through the network-here operationalized as directional betweenness centrality (see Brass \& Burkhardt, 1992). These two measures are useful when studying institutional fit, as they indicate how important an actor is both locally in the network (degree) and as a broker connecting different parts of the network (betweenness).

\section{Methodology}

A single-case study research design with multiple embedded units of analysis was used to address the research question, focusing on one catchment area comprising several municipalities, many organizations, and numerous individual actors contributing to flood risk mitigation. To grasp the complexity of flood risk, the case study also includes the rest of the municipality where the selected river meets the sea that is exposed to other types of floods. Social network analysis and qualitative research were applied, as the former has proved useful to unravel underlying processes (Robins, Lewis, \& Wang, 2012) while the latter is useful to unveil their reasons and meaning (Bernard, 2006).

The case study was selected using the logic of the extreme case. To be considered extreme has less to do with extreme magnitudes of flood risk and more with the complexity of the flood problem. Höje $\AA$ is a river catchment area in Southern Sweden that fits that description, being exposed to as all types of floods and comprising three dynamically developing municipalities with significant changes in terms of population growth and urbanization, exploitation of new areas, and densification of existing areas (Figure 1). The catchment area covers $316 \mathrm{~km}^{2}$ and has a population of around 150,000 inhabitants. Intense human activity has over the last two centuries altered the hydrological connectivity considerably (Figure 1), resulting in upstream activities having significant effects on downstream river flow.

Data was collected using interviews, with a structured part to collect quantitative data for the social network analysis and an unstructured part to collect more qualitative data for the interpretative analysis. Since many actors contributing to mitigating flood risk were unknown from the outset, the respondents were

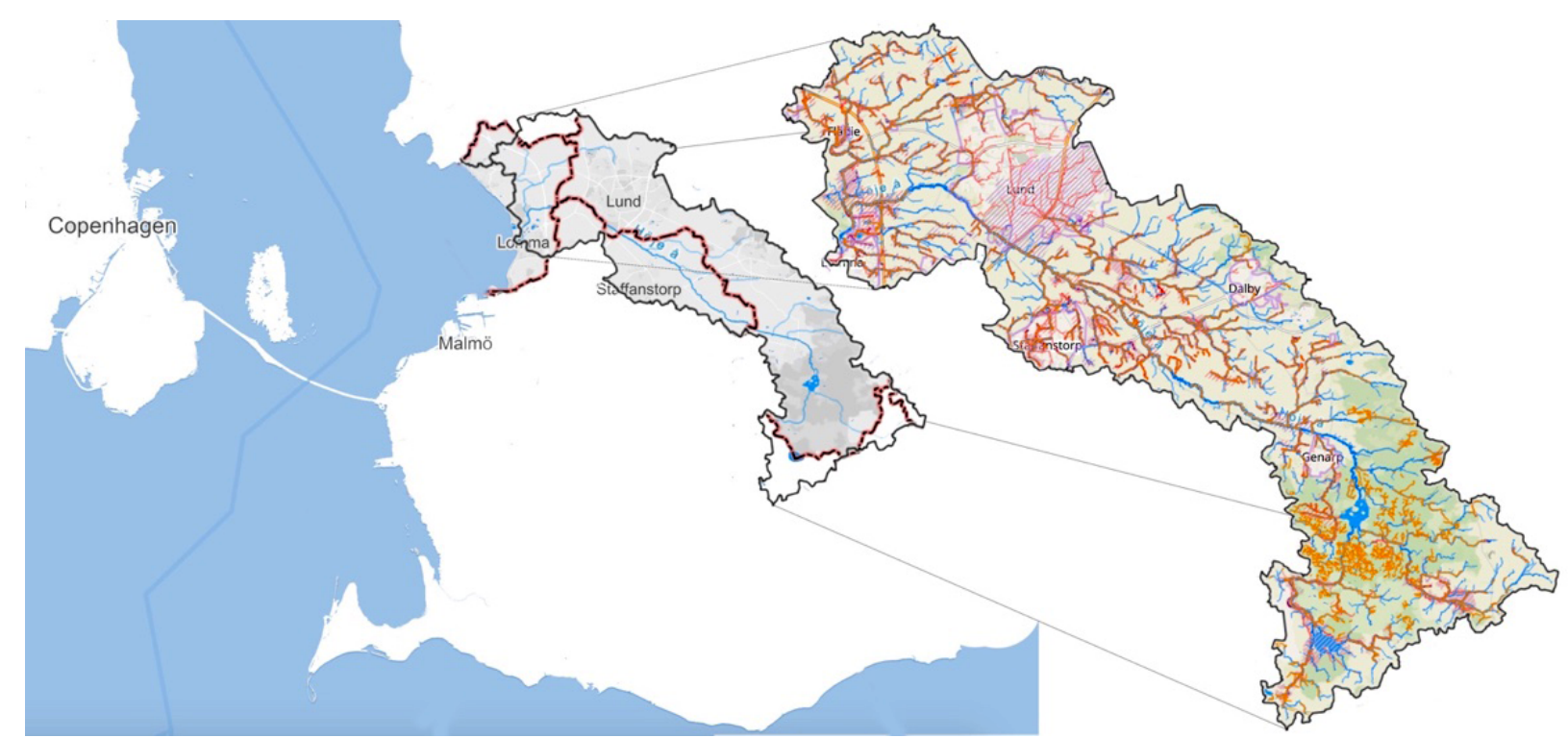

Figure 1. Location of the case study and sketch of the hydrological connectivity of Höje Å catchment area. Developed from www.vattenatlas.se. 
selected by means of snowballing (Borgatti et al., 2018). The snowballing started with 10 respondents within each municipal administration identified as likely to contribute to the mitigation of flood risk, using a namegenerating question concerning who each respondent depends upon for input to be able to contribute to mitigating flood risk. It continued until no more new respondents were identified. This resulted in 217 respondents contributing actively to flood risk mitigation in the case study, interviewed between January 2017 and October 2018. The respondents also identified 256 other actors on whom they depend for some input, but who are not contributing actively or cannot be interviewed; i.e., deceased, quitted job, not considering themselves contributing, or performing purely technical tasks (e.g., maintaining a pump, flushing a pipe, running a software). This category also includes a few instances of respondents referring to groups instead of an individual (e.g., a municipal call center, an organization). See Table 1 for an overview of the types of actors these 217 actively contributing actors and 256 supporting actors are, and what types of organizations they represent.
The social network data was collected through structured interviews using a questionnaire with questions about different attributes (organization, gender, age, work experience, and education) and ties to the other actors identified by each respondent. The dependence between actors was operationalized as the importance of the seven different types of input listed above, rated on a five-point Likert scale from not at all (0) to extremely important (4). The importance of the different inputs was then aggregated and normalized (divided by the maximum possible sum of 28 ) to produce a scale between zero (no importance) and one (maximum importance). The participants were also asked to rate the level of trust they have that they will be provided with the input they need from each identified actor, the level of influence these actors have over their ability to contribute to mitigate flood risk, and the type of relationship they have, but these results are not used in this article. Qualitative data was collected through an open qualitative question during the interviews, asking the respondents who, what organization, part of which organization, or type of actor in the entire universe they consider having the most influ-

Table 1. Overview of the types of organizations and actors involved in governing flood risk mitigation.

\begin{tabular}{|c|c|}
\hline Organization & Types of actors \\
\hline $\begin{array}{l}\text { Staffanstorp municipal } \\
\text { administration }\end{array}$ & $\begin{array}{l}\text { Politicians, senior managers, civil servants (water and sewage, planning, roads, land } \\
\text { and exploitation, environment, project management) }\end{array}$ \\
\hline $\begin{array}{l}\text { Lund municipal } \\
\text { administration }\end{array}$ & $\begin{array}{l}\text { Politicians, senior managers, civil servants (planning, risk and vulnerability, park and nature, } \\
\text { children and education, roads and traffic, legal, strategic development, surveying, housing, } \\
\text { building permits, waste management, land and exploitation, environmental protection, } \\
\text { environmental strategy) }\end{array}$ \\
\hline $\begin{array}{l}\text { Lomma municipal } \\
\text { administration }\end{array}$ & $\begin{array}{l}\text { Politicians, senior managers, civil servants (water and sewage, planning, risk and vulnerability, } \\
\text { building permits, finance, property management, roads, parks, GIS, land and exploitation, } \\
\text { environmental strategy, project management, surveying, service center) }\end{array}$ \\
\hline VA SYD & Senior managers, civil servants (water and sewage) \\
\hline $\begin{array}{l}\text { Other municipal } \\
\text { organizations }\end{array}$ & $\begin{array}{l}\text { Civil servants (representatives of the Fire and Rescue Services, the Erosion Damage Centre, } \\
\text { a neighboring municipality outside the catchment area, and a municipality in another part } \\
\text { of Sweden) }\end{array}$ \\
\hline $\begin{array}{l}\text { County Administrative } \\
\text { Board }\end{array}$ & $\begin{array}{l}\text { Senior managers, civil servants (planning, climate, environment, water, fishing and recovery, } \\
\text { GIS) }\end{array}$ \\
\hline National authorities & $\begin{array}{l}\text { Politician, civil servants (planning, agriculture, climate and hydrology, risk and vulnerability, } \\
\text { environment, geology, oceans and water, surveying, traffic, enterprise and innovation, } \\
\text { government office) }\end{array}$ \\
\hline Universities & Researchers (representatives of Lund University and Swedish University of Agricultural Sciences) \\
\hline Consultants & Consultants (representatives of more than 30 companies spanning various fields) \\
\hline Other companies & Various contractors, construction companies, insurance companies, etc. \\
\hline Landowners & Large landowners \\
\hline Citizens & Particular groups of citizens mentioned as providing important input \\
\hline Others & Others \\
\hline
\end{tabular}


ence over the mitigation of flood risk in the catchment area. The question was probed until the respondents could not list more (no rank), or a maximum of five had been listed. Qualitative data was also collected through the informal interviews ensuing from the conversations around the formal interview parts.

Each interview took between 60 and 90 minutes, with a few shorter interviews with actors less engaged in flood risk mitigation. All interviews but six were done face-to-face to minimize non-responses and to allow for clarifications and probing (Borgatti et al., 2018) as well as the informal interviews. The remaining interviews had to be done over the phone for logistical reasons and were all with peripheral actors (individual consultants or representatives of national authorities). The social network data was analyzed with the assistance of the software UCINET (Borgatti, Everett, \& Freeman, 2002) and the qualitative data was analyzed using a series of coding and categorizations (Charmaz, 2006).

\section{Results}

Regardless of how water flows in the landscape, the Swedish legal framework concentrates the responsibility for flood risk mitigation on municipal administrations. Even if the results demonstrate that a broad range of actors are involved in the governing of flood risk mitigation in the studied case (Table 1), the network centers on the three municipal administrations (Figures 2 and 3 ). The legal framework confers sovereign right to municipal administrations to adopt land use plans (Swedish Parliament, 2010), explicitly pointing out considerations for flood risk (Swedish Parliament, 2010, Chapter 2, Section 5). It allocates to them the responsibility for removing surface water from settled areas (Swedish Parliament, 2006a). The legal framework further stipulates that municipal administrations must have an 'action program' to mitigate risk (Swedish Parliament, 2003) and regularly assess risk and vulnerability within their jurisdiction (Swedish Parliament, 2006b). The formal guidelines for municipal action programs and risk and vulnerability analyses both highlight flood risk explicitly (MSB, 2011a, 2011b). Although the legal framework started to explicitly demand considerations of flood risk already in the mid-1980s (Swedish Government, 1985; Swedish Parliament, 1986, 1987), it was not until the floods of 2007 that flood risk started to become a priority issue in the catchment area: "Everything started with the floods in 2007" (male head of department). It is, however, important to note that water and sewage is outsourced by Lund municipal administration to VA SYD-a regional organization owned by a number of

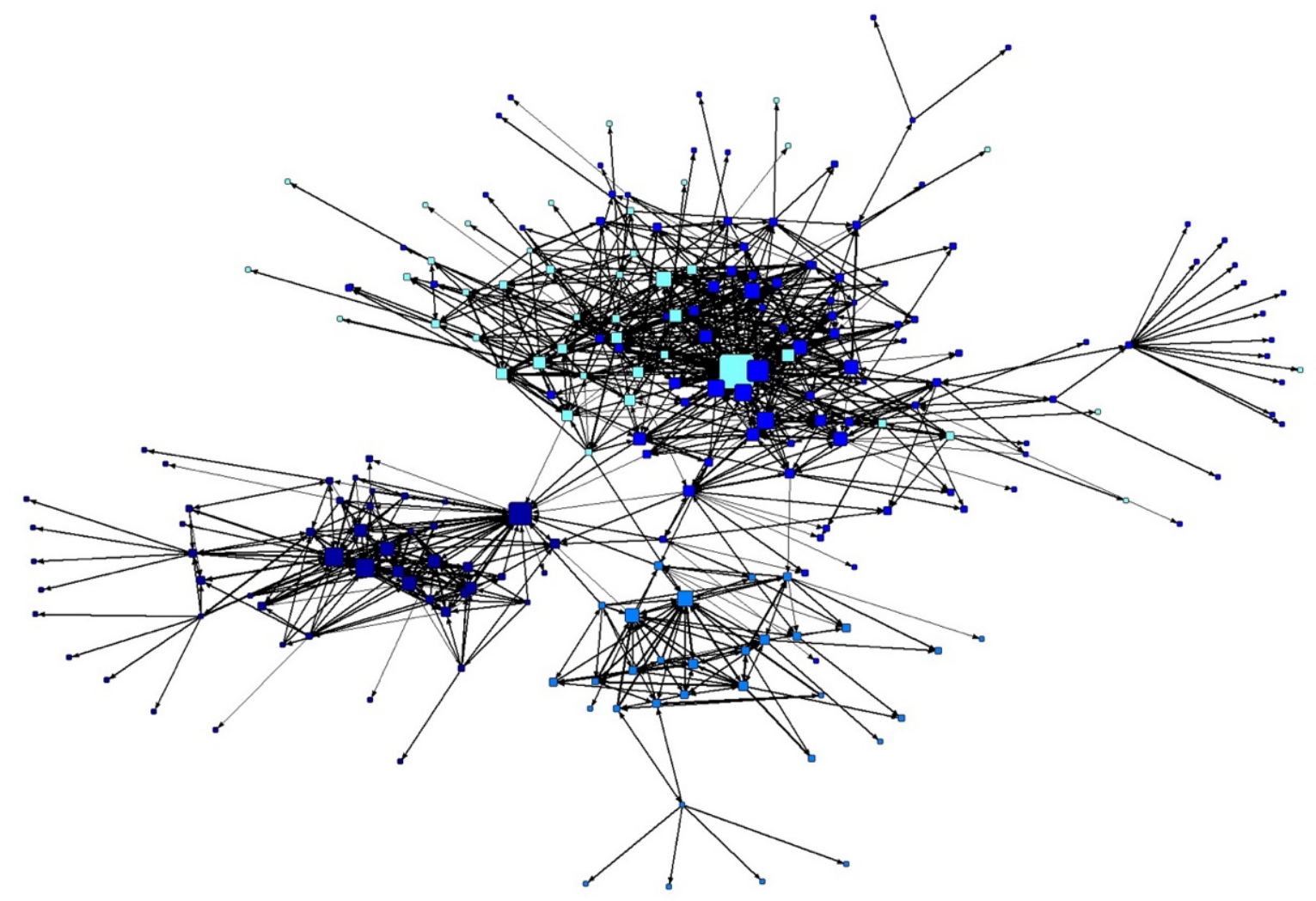

Figure 2. The three municipal administrations and local importance of actors. Notes: Node size = local control of resources (in-degree centrality). Line thickness = tie strength (total normalized input). Node color = Lomma municipal administration (dark blue), Lund municipal administration (middle blue), Staffanstorp municipal administration (light blue), VA SYD (turquoise). 


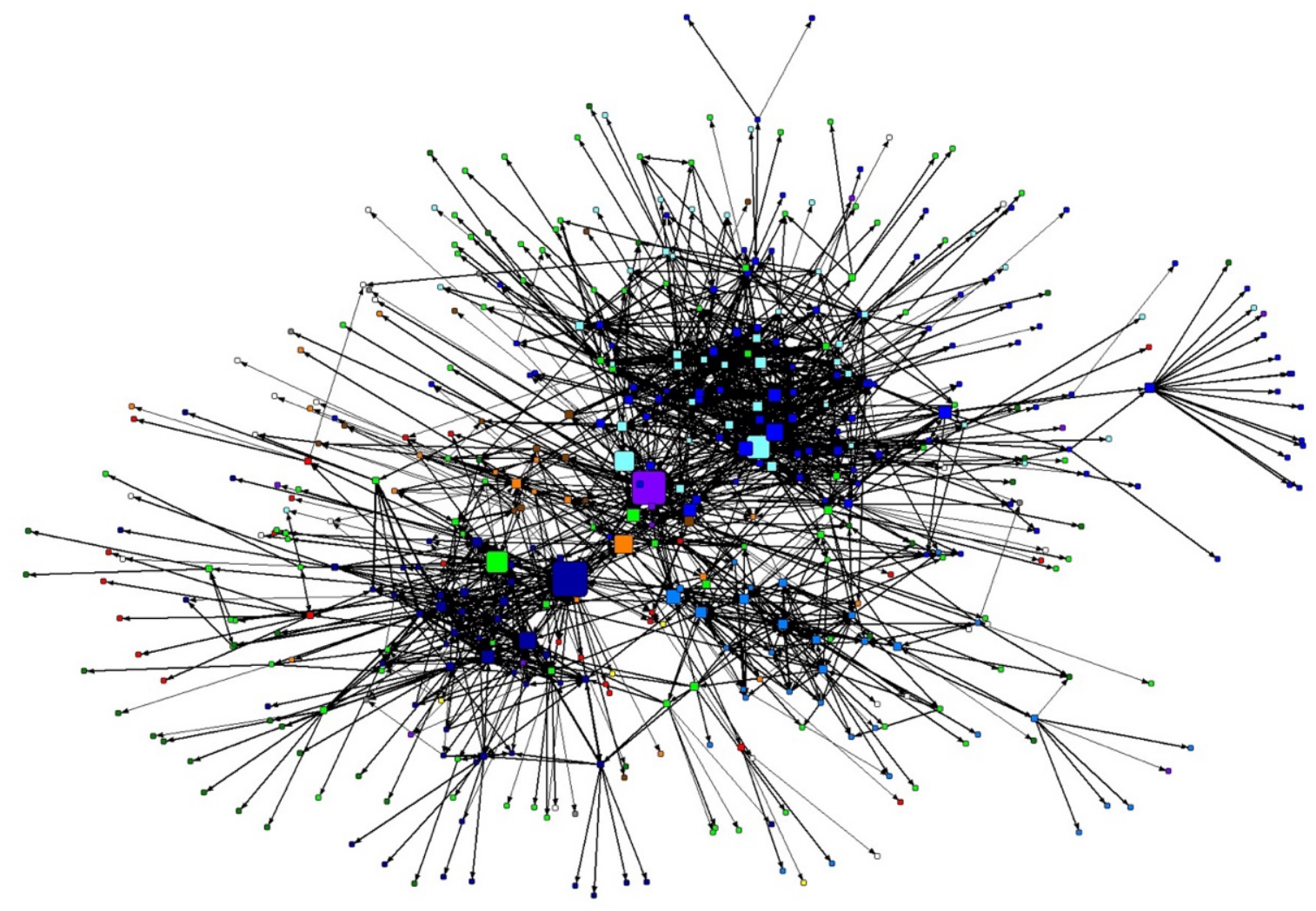

Figure 3. Control over resource flows connecting the total network of actors. Notes: Node size $=$ control over resource flows (directional betweenness centrality). Line thickness $=$ tie strength (total normalized input). Node color $=$ Lomma municipal administration (dark blue), Lund municipal administration (middle blue), Staffanstorp municipal administration (light blue), other municipal organizations (purple), VA SYD (turquoise), County Administrative Board (orange), national authorities (red), universities (yellow), consultants (light green), other companies (dark green), landowners (brown), citizens (grey), others (white).

municipalities-and actors from both organizations are needed for comparison with the other two municipal administrations (Figure 2).

\subsection{A Problem of Fit between Municipalities}

Concentrating responsibility for mitigating flood risk to municipal administrations would not necessarily lead to a problem of fit on the catchment level, provided sufficient coordination between municipalities. However, the direct interaction between the municipal administrations suggests the opposite (Figure 2). The relatively little interaction largely involves actors representing the municipal administrations on Höje Å River Council, which is a voluntary association of municipalities, industries, water treatment companies, and others affected by the water in the catchment area. While several of these representatives have prominent appointments in the bureaucratic hierarchies of each municipality, they are relatively marginal in the networks of actors mitigating flood risk within them. It is only in Lomma where a representative is structurally important for the activities within the municipal administration (Figure 2). However, no actor in Lomma municipal administration declares to receive any input from the municipal administrations upstream, indicating negligible direct coordination concerning flood risk mitigation between the three municipal administrations.

When analyzing the entire network of actors, there are indirect interactions between the municipal administrations through actors representing other organizations linking them to various degrees. Most notably a central actor of the River Council (purple in Figure 3). While the River Council is intended to have a coordinating role in water related issues in the catchment area, it is a voluntary association without decision-making power and little influence over the three municipal administrations. It is as such mainly a platform for dialogue, even if its driven staff has managed to attract funding to implement a number of standalone projects along the river concerning both water quantity and quality. Among the representatives of the municipal administrations on the River Council, it is only the representative from Lomma who is important enough within her municipal administration locally to assume that any input from the River Council significantly influences flood risk mitigation there (Figures 2 and 3). In addition to the representatives of the municipal administrations to the River Council, 
there are only two other actors in Lomma and three in Staffanstorp receiving input from the River Council, while there are 16 in Lund and 8 at VA SYD. This stark difference is explained by the staff of the River Council not only technically being employees of Lund municipal administration, but their office also being hosted in its main building. Actors in Lund thus see them as colleagues to ask water related questions, as evident in several interviews, for example: "When I have some water-related issue related to a detailed development plan I am working on, I usually walk over and talk to [name]. He knows a lot and takes his time to share his opinion" (male civil servant). There is also one actor representing the County Administrative Board with somewhat of a brokering position (orange in Figure 3), but only providing input to four actors in Lomma and one in Staffanstorp. The weak coordinating role of the Country Administrative Board is also evident in the qualitative part of the interviews, where none of the respondents mentions anything about coordination in relation to the regional authority.

The results of the open qualitative question about influence over the mitigation of flood risk in the catchment area are informative for grasping this problem of fit, indicating the prevalence of different modes of thinking about flood risk mitigation among the involved actors. The results demonstrate that a municipal perspective is completely dominant, with almost all participants including municipal actors in their modes of thinking about the most influential actors; in contrast to only one in five including actors influencing upstream hydrology (Figure 4). Almost half include either only municipal actors-indicating pure municipal modes of thinkingor also actors on other administrative levels-indicating hierarchical modes of thinking. This is in sharp contrast to only one actor voicing an equally pure hydrological mode of thinking. The hydrological perspective is more often mixed with municipal or hierarchical modes of thinking, with local modes of thinking stressing the importance of citizens and property owners, or with several other perspectives composing mixed modes of thinking without a discernible core (Figure 4).

These diverse modes of thinking about flood risk mitigation are also clearly visible in the results from the qualitative part of the interviews, with different actors voicing different and often conflicting views on both issues and solutions. Although municipal or hierarchical modes of thinking are dominant also among actors in Lomma municipal administration downstream, the most influential actors there grasp the hydrological basis of the problem and see increased retention of water upstream as a fundamental part of the solution. For instance: "It is neither possible or fair for us to fix future floods in Lomma by ourselves. The solution must include substantial retention of water upstream" (female civil servant). This is in sharp contrast to the modes of thinking about flood risk mitigation voiced by most upstream actors, who see the solution as more effective drainage of water from their areas. For instance:

The politicians got caught completely off guard by the flood in 2007. Before they didn't do anything. Then they multiplied the investment budget for water and sewage, and we continue to improve [the drainage system] as we go.....We have also invested in large pumps to speed up the removal of water from our system to allow for efficient drainage [of Staffanstorp] even under intense rainfall. (Male civil servant)

Flooded fields are problematic for agriculture. Most of the agricultural drainage we had for our fields were getting too old and not working properly. We recently renovated several of the most problematic areas, so we hope that they will have the right capacity to drain the fields quickly in the future. (Male landowner)

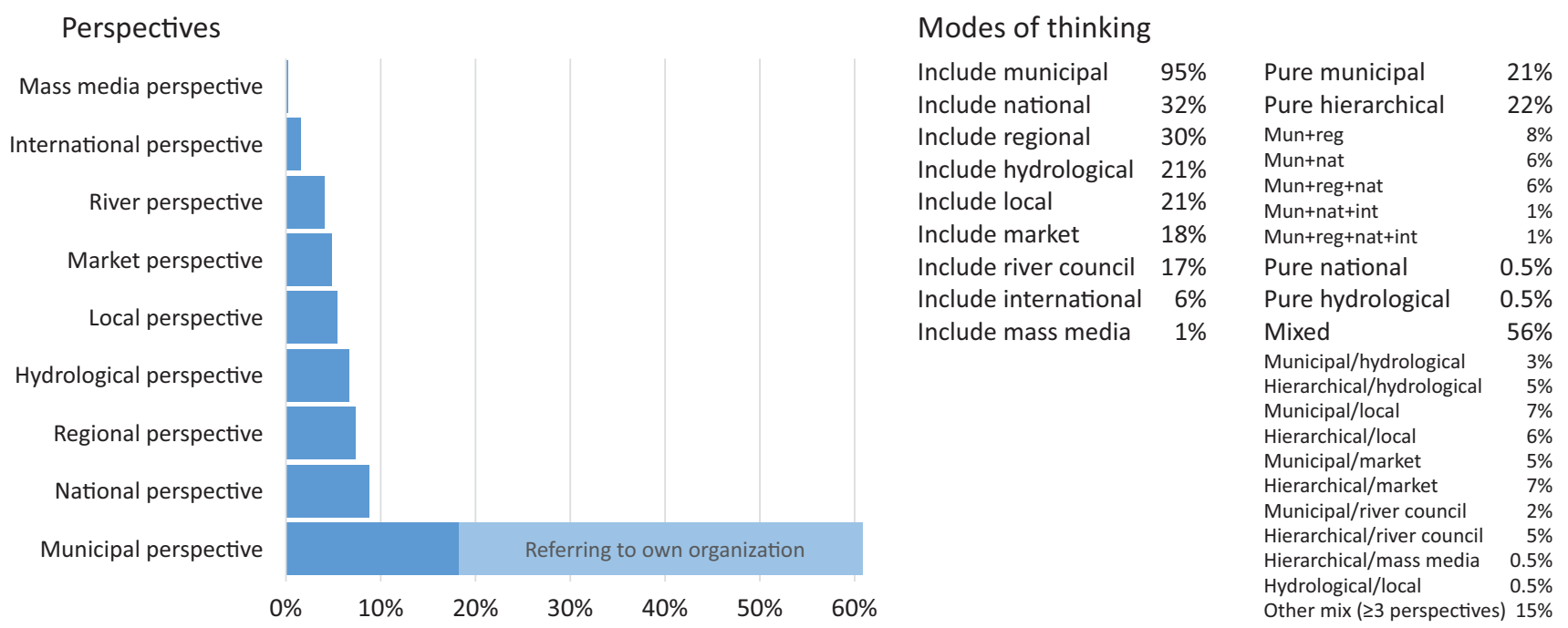

Figure 4. Elicited distribution of perspectives and associated modes of thinking in actors' accounts of influence over flood risk mitigation in the selected case. 
It is important to note that the present study does not provide any data for evaluating which course of action to take; between increasing upstream retention of floodwater to reduce flood risk downstream and increasing upstream drainage capacity to reduce flood risk locally. What is important here is that these two opinions are both locally rational, but contradictory in the governing of flood risk mitigation.

\subsection{A Problem of Fit within Municipalities}

Water is not only flowing from upstream to downstream across municipal borders but along sub-catchments in the landscape in general. Although included as a planning assumption in the comprehensive plans for all three municipalities, it is in the detailed development planning for specific areas that the mitigation of flood risk is addressed in practice (Figure 5). However, the issue here is that flood risk is addressed for each planning area in isolation:

Floods are a priority in the building of new areas, but it is taken care of in the projects. Water and sewage expertise is always involved in the planning to make sure the drainage system for the new area is correct. (Female civil servant)

Water has always been considered, but when floods became a higher priority we had to try new ways of working together. Also now, with the project 'Lund's Water.' We find a way that works, and stick to it. This is how we do it. (Male civil servant)
The developer requesting the detailed development plan (including the municipality) is legally required to provide the necessary assessments of flood risk for that specific area. The borders of the area therefore usually follow land ownership, without any hydrological significance, and the assessments only focus on the planning area as such and based on the planned situation within the area and the current situation of the areas around. This practice ignores not only the potential impacts of the planned development on other planning areas today, but also tomorrow. This is recognized as potentially problematic by some planners:

Yes, it is perhaps problematic, but that is how planning must be done. How should flood risk be assessed otherwise? The law says that it is the landowner who must show that flood risk is taken into account and they pay for the necessary assessments. They cannot be forced to pay for assessments of flood risk for areas bigger than the area they own and have requested a detailed development plan for. Who should pay for it then? This is how planners in Sweden do it. (Female civil servant).

The resulting plan is a comprehensive document, spanning myriad sectors and interests, based on a complex set of planning specifications. However, many such specifications cannot be regulated after the plan has been approved and the area developed, while the municipal administration is solely responsible for urban drainage and flood risk mitigation regardless: "We who work with water and sewage are, of course, very dependent of what

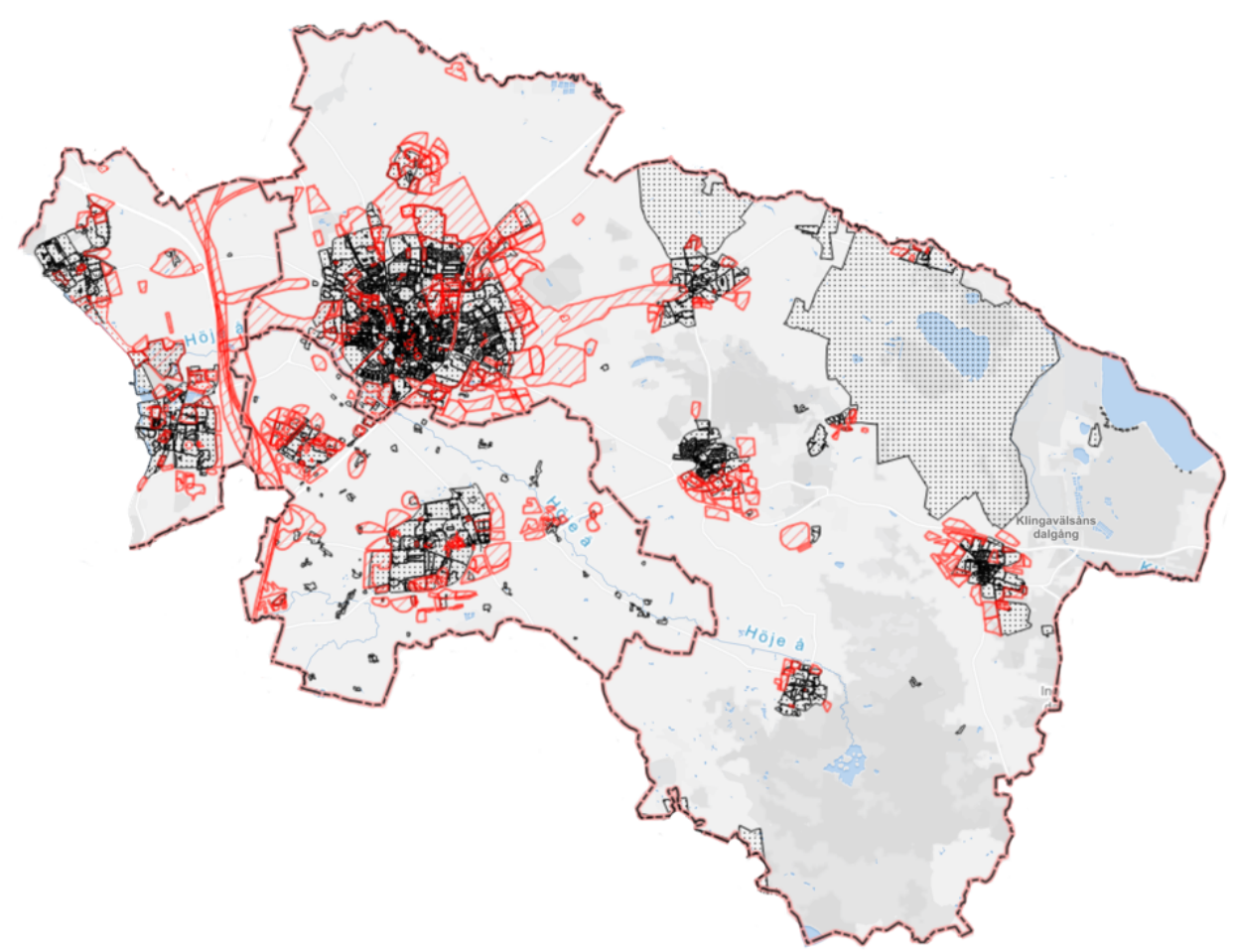

Figure 5. Planning areas in the three municipalities. Developed from www.vattenatlas.se. 
they [planners] do....I trust them fully, but there are difficulties in the contribution of planning to [flood] mitigation in the legislation" (female civil servant).

\section{Discussion}

The results suggest an evident problem of fit between the hydrology of the catchment area and the regime of practices of individual actors governing flood risk mitigation within it. Even when it is obvious that water flows downwards in the landscape, across whatever borders, there is a problem of fit both between the municipalities constituting Höje Å catchment area and within each municipality itself. This problem of fit emerges in the 'governmentalization' of flood risk mitigation; in the particular processes of institutionalization that turn flood risk mitigation into something requiring governing on a societal level. It is a result of regulative, normative, and culturalcognitive demands under overwhelming complexity.

The institutionalization of flood risk mitigation is neither detached from the past, nor unfolding in a vacuum. Understanding the decoupling between organizations within an organizational field, as well as between different planning areas of each organization, entails paying attention to the many micro-level events in which actors faced with a new situation co-invent ways to deal with it. When flood risk mitigation started to attract increasing attention after the floods in 2007, which were not catastrophic on any international scale but enough to call attention to the issue, it was the actors ensuring sufficient urban drainage for more everyday rainfall who got involved first. The already established practices of these actors, mainly focusing on water and sewage or planning within each of the three municipalities, provided initial patterns of activities from which the regime of practices of flood risk mitigation evolved. As the legal requirements for urban drainage of these two policy areas (Swedish Parliament, 2006a, 2010) had been regarded as met by piecemeal attention to it ever since flood risk was first considered in the Swedish legal framework in the mid-1980s (Swedish Government, 1985; Swedish Parliament, 1987), the same decoupled practices were initially applied and rather rapidly becoming the established practice also for flood risk mitigation. Hence, resulting in mere ceremonial compliance (cf. Meyer \& Rowan, 1977). This corresponds well to Van de Ven and Garud's (1994) suggestion that after a period of events with actors testing and adjusting activities as they go along, particular patterns of activities begin to be selected more and more often (rulemaking events) until they dominate and become the convention (rule-following events). It is then of particular importance to understand why these decoupled practices are continuously reproduced, even when increasingly evident for certain actors that such practices are fundamentally flawed when governing flood risk mitigation. North's (1990) explanation resonates particularly well with the results, emphasizing increasing costs of changing to an alternative practice over time, while further work in the same direction is still rewarded. Such problems of 'increasing returns' are particularly common when feedback is fuzzy and evaluations subjective (North, 1990), such as in the mitigation of flood risk, and organizational decoupling more likely when there are high costs associated with closer integration (Scott, 2014, p. 187). Status quo is then maintained through a combination of actors being reluctant to consider alternatives after having invested time and energy to learn the current practices (learning effects), the contribution of each actor being facilitated by others following the same practices (coordination effects), and new actors being motivated to adopt the current practices as they appear commonly accepted (adaptive expectations; North, 1990).

However, it is not only through incentives that institutions are holding actors hostage to their own history, but also through their normative order that is both constituting and being constituted by actors over time (Selznick, 1992, p. 232). This is clear in the empirical material, with respondents expressing in different ways that 'this is the way we do it' and giving references to the common practices of their different professional groups (cf. Scott, 2014). Although closely related to coordination effects (North, 1990), such normative expectations are invaluable as they "reduce the need for constant negotiation of expectations and behavioural contracts" (Handmer \& Dovers, 2007, p. 30), but can clearly also bind actors to flawed practices. The empirical material is also rife with examples of respondents expressing that 'this is how it is done,' which is a usual indicator of more cultural-cognitive elements of institutionalization (Berger \& Luckmann, 1966, p. 77; Scott, 2014, p. 148). Here it is not about incentives or identity, but about the objectification of shared ideas about central aspects of flood risk mitigation. This also includes the taken for granted; most clearly visible in the pervasive but tacit influence of the municipal borders, which are still largely delineated by the medieval parishes originally formed to provide viable congregations to already constructed churches and could have been drawn in very different ways. Such objectification involves the development and diffusion of some degree of consensus among actors concerning the meaning and value of the ideas, where the diffusion shifts from mere imitation to being increasingly normative with less and less room for alternative views (Tolbert \& Zucker, 1996). These shared ideas thus "thicken" and "harden" when diffused (Berger \& Luckmann, 1966, p. 76); not only for the newly incorporated actors, but also for the actors already subscribing to the particular understanding.

The problem of fit in flood risk mitigation is the combined result of regulative, normative, and culturalcognitive elements, and it has been shown that it is when such different elements align that their combined force is most formidable (cf. Scott, 2014, pp. 70-71). However, the 'governmentalization' of flood risk mitigation is not determined by the processes of institution- 
alization in isolation. It is also influenced by the complexity of the environment they are operating in. While many organizational theorists have focused mainly on the institutional environment as such (see Scott, 2014, pp. 196-198), the complexity of the issue requiring governing is also important (Berardo \& Scholz, 2010). It is when the complexity of the issue of flood risk mitigation, in terms of both hydrology and institutional environment, overwhelms actors involved in governing it, that decoupling provides a means to reduce the issue into parts that can be addressed one by one to comply with detailed legal requirements. However, such rationalization undermines effective governing of flood risk mitigation, since the law of requisite variety stipulates that any system governing another larger complex system must have a degree of complexity comparable to the system it is governing (Ashby, 1957).

Finally, it is important to note that the identified problem of fit would not necessarily have been visible in more conventional studies of institutional fit focusing on the institutional level as such (macro) or on the interaction between organizations (meso). Although immensely time-consuming, individual level (micro) studies are thus likely to be needed to provide perspectives necessary for increased understanding of the complexities of risk governance in general.

\section{Conclusions}

There is a distinct problem of fit between the hydrology of Höje $\AA$ catchment area and the regime of practices of individual actors governing flood risk mitigation in it, which is likely to be a common feature across Sweden due to the shared institutional environment but might have been invisible to more conventional macroor meso-level studies. This problem of fit emerges in the 'governmentalization' of flood risk mitigation, with actors responding to and reproducing new institutional demands in a context of overwhelming complexity. It can be explained by attention to incentives, identities, and ideas that align to effectively decouple the regime of practices of flood risk mitigation both between and within municipalities. Although there are different ways to interpret the legal framework for flood risk mitigation, it is being implemented with the focus on compliance to details and not on its overall purpose. However, the resulting decoupled practices are not only cemented through the continual application of the emphasized regulative requirements, but also through normative and cultural-cognitive backings emerging in their repetition and making them influential, indisputable, or even invisible to the involved actors.

\section{Acknowledgments}

This study would not have been possible without the keen participation of the politicians, civil servants and other professionals contributing to mitigating flood risk in the studied case. The study is part of the research project 'Sustainable Urban Flood Management,' which was funded by FORMAS (942-2015-149).

\section{Conflict of Interests}

The author declares no conflict of interests.

\section{References}

Alfieri, L., Bisselink, B., Dottori, F., Naumann, G., de Roo, A., Salamon, P., . . Feyen, L. (2017). Global projections of river flood risk in a warmer world: River flood risk in a warmer world. Earth's Future, 5(2), 171-182. https://doi.org/10.1002/2016EF000485

Artur, L., \& Hilhorst, D. (2017). Climate change adaptation in Mozambique. In P. Martens \& C. T. Chang (Eds.), The Social and Behavioural Aspects of Climate Change (pp. 114-129). Abingdon and New York, NY: Routledge.

Ashby, W. R. (1957). An introduction to cybernetics. London: Chapman \& Hall Ltd.

Aven, T., \& Renn, O. (2009). On risk defined as an event where the outcome is uncertain. Journal of Risk Research, 12, 1-11. https://doi.org/10.1080/ 13669870802488883

Becker, P. (2014). Sustainability science: Managing risk and resilience for sustainable development. Amsterdam and Oxford: Elsevier.

Becker, P. (2018). Dependence, trust, and influence of external actors on municipal urban flood risk mitigation: The case of Lomma Municipality, Sweden. International Journal of Disaster Risk Reduction, 31(1004), 1004-1012. https://doi.org/10.1016/j.ijdrr.2018.09. 005

Berardo, R., \& Scholz, J. T. (2010). Self-organizing policy networks: Risk, partner selection, and cooperation in estuaries. American Journal of Political Science, 54(3), 632-649. https://doi.org/10.1111/ j.1540-5907.2010.00451.x

Berger, P. L., \& Luckmann, T. (1966). The social construction of reality. London and New York, NY: Penguin Books.

Bergsma, E. (2019). The development of flood risk management in the United States. Environmental Science \& Policy, 101, 32-37. https://doi.org/10.1016/ j.envsci.2019.07.013

Bergsten, A., Jiren, T. S., Leventon, J., Dorresteijn, I., Schultner, J., \& Fischer, J. (2019). Identifying governance gaps among interlinked sustainability challenges. Environmental Science \& Policy, 91, 27-38. https://doi.org/10.1016/j.envsci.2018.10.007

Berkowitz, S. D. (1982). An introduction to structural analysis: The network approach to social research. Toronto: Butterworth.

Bernard, H. R. (2006). Research methods in anthropology: Qualitative and quantitative approaches. Lanham, MD: AltaMira Press. 
Bodin, Ö., \& Nohrstedt, D. (2016). Formation and performance of collaborative disaster management networks: Evidence from a Swedish wildfire response. Global Environmental Change, 41, 183-194. https:// doi.org/10.1016/j.gloenvcha.2016.10.004

Borgatti, S. P., Everett, M. G., \& Freeman, L. C. (2002). Ucinet for Windows: Software for social network analysis. Harvard, MA: Analytic Technologies.

Borgatti, S. P., Everett, M. G., \& Johnson, J. C. (2018). Analysing social networks. London and Thousand Oaks, CA: SAGE Publications.

Brass, D. J., \& Burkhardt, M. E. (1992). Centrality and power in organizations. In N. Nohria \& R. G. Eccles (Eds.), Networks and organizations: Structure, form, and action (pp. 191-215). Boston, MA: Harvard Business School Press.

Charmaz, K. (2006). Constructing grounded theory: A practical guide through qualitative analysis. London and Thousand Oaks, CA: Sage Publications.

Coppola, D. P. (2011). Introduction to international disaster management. Oxford: Butterworth-Heinemann.

Crossley, N. (2010). Networks and complexity: Directions for interactionist research? Symbolic Interaction, 33, 341-363. https://doi.org/10.1525/si.2010.33.3.341

Davie, T. (2008). Fundamantals of hydrology. London and New York, NY: Routledge.

Di Baldassarre, G., Nohrstedt, D., Mård, J., Burchardt, S., Albin, C., Bondesson, S., . . . Parker, C. F. (2018). An integrative research framework to unravel the interplay of natural hazards and vulnerabilities. Earth's Future, 6(3), 305-310. https://doi.org/ 10.1002/2017EF000764

DiMaggio, P. J. (1992). Nadels paradox revisited: Relational and cultural aspects of organizational structure. In N. Nohria \& R. G. Eccles (Eds.), Networks and organizations: Structure, form, and action (pp. 118-142). Boston, MA: Harvard Business School Press.

Emirbayer, M. (1997). Manifesto for a relational sociology. American Journal of Sociology, 103, 281-317.

Emirbayer, M., \& Goodwin, J. (1994). Network analysis, culture, and the problem of agency. American Journal of Sociology, 99, 1411-1454.

EU. (2007). Directive 2007/60/EC of the European Parliament and of the Council of 23 October 2007 on the assessment and management of flood risks. Official Journal of the European Union, L288, 27-34.

Fine, G. A. (1993). The sad demise, mysterious disappearance, and glorious triumph of symbolic interactionism. Annual Review of Sociology, 19, 61-87.

Folke, C., Lowell Pritchard, J., Berkes, F., Colding, J., \& Svedin, U. (2007). The problem of fit between ecosystems and institutions: Ten years later. Ecology and Society, 12(1). https://doi.org/10.5751/ES02064-120130

Fuhse, J. A., \& Mützel, S. (2011). Tackling connections, structure, and meaning in networks: Quantitative and qualitative methods in sociological net- work research. Quality and Quantity, 45, 1067-1089. https://doi.org/10.1007/s11135-011-9492-3

Goffman, E. (1982). The interaction order: American Sociological Association, 1982 Presidential address. American Sociological Review, 48, 1-17.

Grahn, T., \& Nyberg, L. (2017). Assessment of pluvial flood exposure and vulnerability of residential areas. International Journal of Disaster Risk Reduction, 21(367), 367-375. https://doi.org/10.1016/ j.ijdrr.2017.01.016

Granovetter, M. S. (1973). The strength of weak ties. American Journal of Sociology, 78, 1360-1380.

Grobicki, A., Macleod, F., \& Pischke, F. (2015). Integrated policies and practices for flood and drought risk management. Water Policy, 17, 180-194. https://doi.org/ 10.2166/wp.2015.009

Handmer, J. W., \& Dovers, S. (2007). The handbook of disaster and emergency policies and institutions. London: Earthscan.

Harjanne, A., Pagneux, E., Flindt Jørgensen, L., Perrels, A., van der Keur, P., Nadim, F., . . Raats, E. (2016). Resilience to natural hazards: An overview of institutional arrangements and practices in the Nordic countries. Reykjavík: NORDRESS.

Hood, C., Rothstein, H., \& Baldwin, R. (2001). The government of risk: Understanding risk regulation regimes. Oxford: Oxford University Press.

Hotimsky, S., Cobb, R., \& Bond, A. (2006). Contracts or scripts? A critical review of the application of institutional theories to the study of environmental change. Ecology and Society, 11(1), 1-10.

Ingold, K., Balsinger, J., \& Hirschi, C. (2010). Climate change in mountain regions: How local communities adapt to extreme events. Local Environment, 15, 651-661. https://doi.org/10.1080/ 13549839.2010.498811

Joas, H. (1987). Symbolic interactionism. In A. Giddens \& J. H. Turner (Eds.), Social theory today (pp. 82-115). Stanford, CA: Stanford University Press.

Johannessen, Å., Gerger Swartling, Å., Wamsler, C., Andersson, K., Arran, J. T., Hernández Vivas, D. I., \& Stenström, T. A. (2019). Transforming urban water governance through social (triple-loop) learning. Environmental Policy and Governance, 18(11), 86-11. https://doi.org/10.1002/eet.1843

Johannessen, Å., \& Granit, J. J. (2015). Integrating flood risk, river basin management and adaptive management: Gaps, barriers and opportunities, illustrated by a case study from Kristianstad, Sweden. International Journal of Water Governance, 3, 5-24. https:// doi.org/10.7564/13-IJWG30

Kim, J., \& Hastak, M. (2018). Social network analysis: Characteristics of online social networks after a disaster. International Journal of Information Management, 38(1), 86-96. https://doi.org/10.1016/ j.ijinfomgt.2017.08.003

Krieger, K. (2013). The limits and variety of risk-based governance: The case of flood management in Ger- 
many and England. Regulation \& Governance, 7(2), 236-257. https://doi.org/10.1111/rego.12009

Lebel, L., Nikitina, E., Pahl-Wostl, C., \& Knieper, C. (2013). Institutional fit and river basin governance. Ecology and Society, 18(1). http://dx.doi.org/10.5751/ES05097-180101

Luhmann, N. (1979). Trust and power: Two works by Niklas Luhmann. Chichester and New York, NY: John Wiley \& Sons.

Meyer, J. W., \& Rowan, B. (1977). Institutionalized organizations: Formal structure as myth and ceremony. The American Journal of Sociology, 83(2), 340-363.

Miller, P., \& Rose, N. (2008). Governing the present: Administering economic, social and personal life. Cambridge: Polity.

MSB. (2011a). Vägledning för kommunala handlingsprogram [Guideline for municipal action programmes]. Karlstad and Stockhom: MSB.

MSB. (2011b). Vägledning för risk och sårbarhetsanalyser [Guideline for risk and vulnerability analyses]. Stockholm: MSB.

Nadel, S. F. (1957). The theory of social structure. Glencoe: Free Press.

Niemczynowicz, J. (1999). Urban hydrology and water management: Present and future challenges. Urban Water, 1(1), 1-14. https://doi.org/10.1016/S14620758(99)00009-6

Norén, V., Hedelin, B., Nyberg, L., \& Bishop, K. (2016). Flood risk assessment: Practices in flood prone Swedish municipalities. International Journal of Disaster Risk Reduction, 18, 206-217. https://doi.org/ 10.1016/j.ijdrr.2016.07.003

North, D. C. (1990). Institutions, institutional change and economic performance. Cambridge: Cambridge University Press.

Priest, S. J., Suykens, C., van Rijswick, H. F. M. W., Schellenberger, T., Goytia, S., Kundzewicz, Z. W., . . Homewood, S. (2016). The European Union approach to flood risk management and improving societal resilience: Lessons from the implementation of the Floods Directive in six European countries. Ecology and Society, 21. http://dx.doi.org/10.5751/ ES-05097-180101

Renn, O. (2008). Risk governance: Coping with uncertainty in a complex world. London and Sterling: Earthscan.

Robins, G., Lewis, J. M., \& Wang, P. (2012). Statistical network analysis for analyzing policy networks. Policy Studies Journal, 40(3), 375-401. https://doi.org/ 10.1111/j.1541-0072.2012.00458.x

Scott, W. R. (2014). Institutions and organizations: Ideas, interests, and identities. Los Angeles, CA and London: Sage.

Selznick, P. (1992). The moral commonwealth: Social theory and the promise of community. Berkeley, CA and Oxford: University of California Press.

Swedish Government. (1985). Proposition om förebyg- gande åtgärder mm mot jordskred och andra naturolyckor (Prop. 1985/86:150 Bil. 3) [Government bill on prevention etc of landslides and other natural accidents]. Stockholm: Swedish Government.

Swedish Parliament. (1986). Räddningstjänstlagen (SFS 1986:1102) [Emergency services law]. Stockholm: Swedish Parliament.

Swedish Parliament. (1987). Plan- och bygglagen (SFS 1987:10) [Planning and building law]. Stockholm: Swedish Parliament.

Swedish Parliament. (2003). Lag om skydd mot olyckor (SFS 2003:778) [Law on the protection against accidents]. Stockholm: Swedish Parliament.

Swedish Parliament. (2006a). Lag om allmänna vattentjänster (SFS 2006:412) [Law on public water services]. Stockholm: Swedish Parliament.

Swedish Parliament. (2006b). Lag om kommuners och regioners åtgärder inför och vid extraordinära händelser i fredstid och höjd beredskap (SFS 2006:544) [Law on municipalities' and regions' actions before and during extraordinary events in peacetime and heighten preparedness]. Stockholm: Swedish Parliament.

Swedish Parliament. (2009). Förordning om översvämningsrisker (SFS 2009:956) [Flood risk ordinance]. Stockholm: Swedish Parliament.

Swedish Parliament. (2010). Plan- och bygglagen (SFS 2009:956) [Planning and building law]. Stockholm: Swedish Parliament.

Thaler, T., \& Levin-Keitel, M. (2016). Multi-level stakeholder engagement in flood risk management: A question of roles and power: Lessons from England. Environmental Science \& Policy, 55(2), 292-301. https://doi.org/10.1016/j.envsci.2015.04.007

Tolbert, P. S., \& Zucker, L. G. (1996). The institutionalization of institutional theory. In S. R. Clegg, C. Hardy, \& W. R. Nord (Eds.), Handbook of organization studies (pp. 175-190). Thousand Oaks, CA and London: SAGE Publications.

Van de Ven, A. H., \& Garud, R. (1994). The coevolution of technical and institutional events in the development of an innovation. In J. A. C. Baum \& J. V. Singh (Eds.), Evolutionary dynamics of organizations (pp. 425-443). Oxford and New York, NY: Oxford University Press.

Wellman, B. (1988). Structural analysis: From method and metaphor to theory and substance. In B. Wellman \& S. D. Berkowitz (Eds.), Social structures: A network approach (Vol. 25, pp. 19-61). Cambridge and New York, NY: Cambridge University Press.

Wisner, B., Blaikie, P. M., Cannon, T., \& Davis, I. R. (2004). At risk: Natural hazards, people's vulnerability and disasters. London: Routledge.

Young, O. R., \& Underdal, A. (1997). Institutional dimensions of global change. Bonn: International Human Dimensions Programme. 


\section{About the Author}

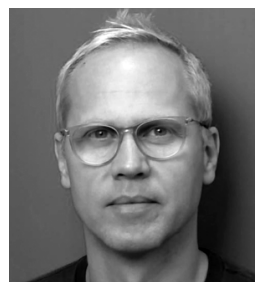

Per Becker is a Reader in Risk and Safety at Lund University in Sweden. He has combined research with a career in humanitarian assistance and international development cooperation focused on disaster risk reduction and climate change adaptation. His research interests focus on the interactions between the physical environment, social organization and social behaviour in relation to societal safety and sustainability. Especially on issues of risk and vulnerability, on what makes society resilient to disturbances, disruptions and disasters, and on capacity development as an intentional process for increasing such resilience. 